Prepared for the U.S. Department of Energy under Contract DE-AC05-76RL01830

\title{
Energy Modeling for the Artisan Food Center
}

S Goel

May 2013

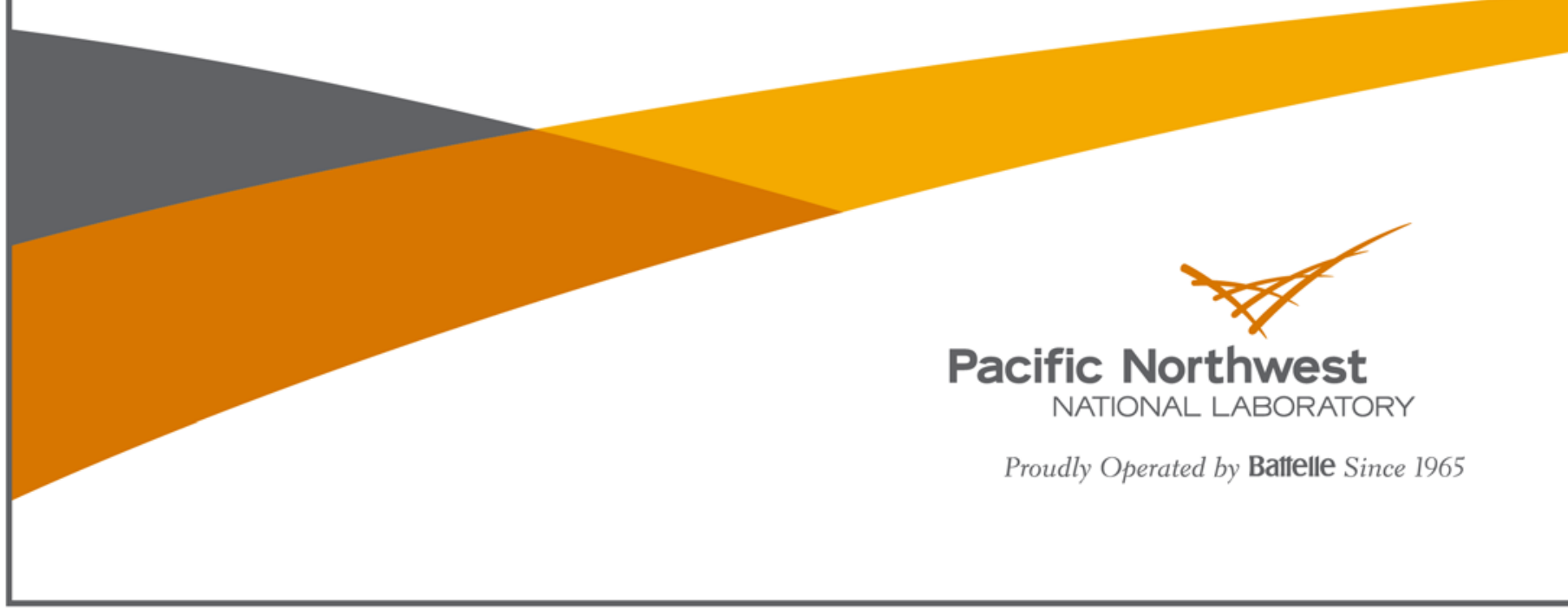




\title{
DISCLAIMER
}

This report was prepared as an account of work sponsored by an agency of the United States Government. Neither the United States Government nor any agency thereof, nor Battelle Memorial Institute, nor any of their employees, makes any warranty, express or implied, or assumes any legal liability or responsibility for the accuracy, completeness, or usefulness of any information, apparatus, produet, or proeess diselosed, or represents that its use would not infringe privately owned rights. Reference herein to any specific commercial product, process, or service by trade name, trademark, manufacturer, or otherwise does not necessarily constitute or imply its endorsement, recommendation, or favoring by the United States Government or any agency thereof, or Battelle Memorial Institute. The views and opinions of authors expressed herein do not necessarily state or reflect those of the United States Government or any agency thereof.

\author{
PACIFIC NORTHWEST NATIONAL LABORATORY \\ operated by \\ BATTELLE \\ for the \\ UNITED STATES DEPARTMENT OF ENERGY \\ under Contract DE-AC05-76RL01830 \\ Printed in the United States of America \\ Available to DOE and DOE contractors from the \\ Office of Scientific and Technical Information, \\ P.O. Box 62, Oak Ridge, TN 37831-0062; \\ ph: (865) 576-8401 \\ email: reports@adonis.osti.gov \\ Available to the public from the National Technical Information Service, \\ U.S. Department of Commerce, 5285 Port Royal Rd., Springfield, VA 2216 \\ ph: (800) 553-6847 \\ (a) $605-6900$ \\ email: orders@ntis.fedworld.gov
}

online ordering: http://www.ntis.gov/ordering.htm

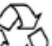

This document was printed on recycled paper

(9/2003) 



\section{Energy Modeling for the Artisan Food Center}

S Goel

May 2013

Prepared for

Strecker Engineering

under US DOE Contract DE-AC05-76RL01830

Pacific Northwest National Laboratory

Richland, Washington 99352 


\subsection{Energy Modeling for the Artisan Food Center}

\subsection{Overview}

The Artisan Food Center is a 6912 sq.ft food processing plant located in Dayton, Washington. PNNL was contacted by Strecker Engineering to assist with the building's energy analysis as a part of the project's U.S. Green Building Council's Leadership in Energy and Environmental Design (LEED) submittal requirements. The project is aiming for LEED Silver certification, one of the prerequisites to which is a whole building energy model to demonstrate compliance with American Society of Heating Refrigeration and Air Conditioning Engineers (ASHRAE) 90.12007 Appendix G, Performance Rating Method. The building incorporates a number of energy efficiency measures as part of its design and the energy analysis aimed at providing Strecker Engineering with the know-how of developing an energy model for the project as well as an estimate of energy savings of the proposed design over the baseline design, which could be used to document points in the LEED documentation.

This report documents the ASHRAE 90.12007 baseline model design, the proposed model design, the modeling assumptions and procedures as well as the energy savings results in order to inform the Strecker Engineering team on a possible whole building energy model.

\subsection{Model Description}

The food-processing center is comprised of seven suites expected to be leased to different food processing companies. The figure below shows a 3D view of the energy model of the building.
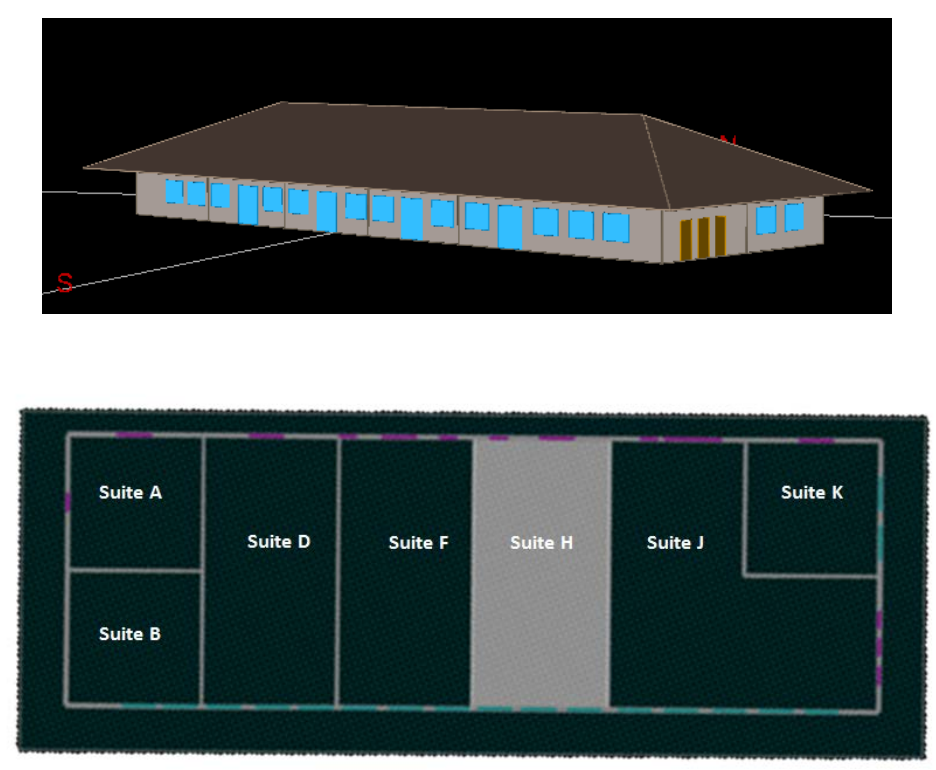

Figure 1. 3D View and Plan of the Artisan Food Center

The models are set in climate zone (CZ) 5B, which is a cool-dry climate which is defined as a region with between 5,400 e and 9,000 heating degree-days $\left(65^{\circ} \mathrm{F} \text { basis }\right)^{1}$.

\footnotetext{
${ }^{1}$ http://apps1.eere.energy.gov/buildings/publications/pdfs/building_america/ba_climateguide_7_1.pdf
} 


\subsection{Envelope: Baseline and Proposed}

Table 1. Envelope Properties for both Proposed and Baseline Design

\begin{tabular}{|c|c|c|c|c|}
\hline \multirow{2}{*}{$\begin{array}{l}\text { Component } \\
\text { Exterior Wall }\end{array}$} & \multicolumn{2}{|l|}{ Proposed Construction } & \multicolumn{2}{|c|}{ Baseline Construction (90.1 2007 CZ 5B) } \\
\hline & $\begin{array}{l}2 \text { x } 6 \text { Wood Frame Wall, } \\
16 \text { " OC Batt Insulation }\end{array}$ & $\mathrm{R}-21$ & $\begin{array}{l}\text { Steel Framed } \\
(2 \times 6,16 " \text { OC) }\end{array}$ & $\begin{array}{l}\text { U-0.064 Btu/h-ft2-F } \\
\text { R-13 + R-7.5 }\end{array}$ \\
\hline Exterior Roof & $\begin{array}{l}\text { 24" OC Wooden Truss } \\
\text { Batt Insulation at the } \\
\text { ceiling }\end{array}$ & $\mathrm{R}-49$ & Insulation above deck & $\begin{array}{l}\text { U-0.048 Btu/h-ft2-F } \\
\text { R-20 ci }\end{array}$ \\
\hline Fenestration & Metal Framing & $\begin{array}{l}\text { U-0.45 Btu/h-ft2-F } \\
{ }^{2} \text { SHGC-0.35 }\end{array}$ & $\begin{array}{l}\text { Metal Framing (All } \\
\text { Other) }\end{array}$ & $\begin{array}{l}\text { U-0.55 Btu/h-ft2-F } \\
\text { SHGC-0.40 }\end{array}$ \\
\hline Exterior Floor & Slab-on-Grade & R-10 for $24 "$ & Slab-on-Grade & R-10 for $24 "$ \\
\hline Door & Metal Door & $\mathrm{U}-0.500 \mathrm{Btu} / \mathrm{h}-\mathrm{ft} 2-\mathrm{F}$ & Metal Door & U-0.500 Btu/h-ft2-F \\
\hline
\end{tabular}

The proposed building envelope is more efficient than the code requirements and results is lower heating and cooling loads.

\subsection{Interior Lighting}

Table 2. Lighting Power Density (LPD) for Proposed and Baseline Design

\begin{tabular}{llrrrr}
\hline & 90.1 Space Type & Area (sq.ft) & $\begin{array}{c}\text { Proposed } \\
\text { Design } \\
\text { Total Watts (W) }\end{array}$ & $\begin{array}{c}\text { Proposed } \\
\text { Design LPD } \\
\text { W/sq.ft }\end{array}$ & $\begin{array}{c}\text { Baseline Design } \\
\text { LPD } \\
\text { W/sq.ft }\end{array}$ \\
\hline Suite A & Food Processing & 576 & 492.8 & 0.856 & 1.2 \\
Suite B & Food Processing & 576 & 719.8 & 1.25 & 1.2 \\
Suite D & Food Processing & 1152 & 969.8 & 0.842 & 1.2 \\
Suite F & Sales Area & 1152 & 688.8 & 0.598 & 1.7 \\
Suite H & Food Processing & 1152 & 904.8 & 0.785 & 1.2 \\
Suite J & Food Processing & 1728 & 1866.6 & 1.08 & 1.2 \\
Suite K & Food Processing & 576 & 618.8 & 1.074 & 1.2 \\
\hline
\end{tabular}

The proposed building has a lower lighting power density for most spaces as compared to 90.12007 requirements. This results in lower lighting energy consumption as well as lower cooling loads due to reduced heat gain through lighting.

\subsection{Process Loads}

Process loads are not accurately known for the building hence a default value of $1.4 \mathrm{~W} / \mathrm{sq}$.ft has been used for both baseline and proposed building. Equipment loads constitute over 35\% of the baseline building's energy use and hence meet the LEED minimum requirements for process loads.

${ }^{2}$ SHGC is solar heat gain coefficient

${ }^{3}$ sq.ft is square feet 


\subsection{HVAC Systems}

The proposed design includes packaged single zone heat pump units serving each suite. The baseline system requirements is a system type 4- Packaged Single Zone Heat Pump, which is in accordance to ASHRAE 90.12007 Appendix G, for a building <25,000 sq.ft, 3 stories or less, with electric heating. The tables below document the baseline and proposed system details including cooling and heating coefficient of performance (COP) and fan power.

Table 3. Baseline System Description

\begin{tabular}{ccccccc}
\hline & \multicolumn{2}{c}{ Cooling } & \multicolumn{2}{c}{ Heating } & \multicolumn{2}{c}{ Fans } \\
Zone & $\begin{array}{c}\text { Capacity }^{4} \\
(\text { Btu/h) })^{5}\end{array}$ & $\begin{array}{c}\text { SEER }^{6} \\
90.12007 \\
\text { Table 6.8.1B }\end{array}$ & $\begin{array}{c}\text { Capacity } \\
(\text { Btu/h) }\end{array}$ & $\begin{array}{c}\text { HSPF }^{7} \\
90.12007 \text { Table } \\
6.8 .1 \mathbf{B}\end{array}$ & $\begin{array}{c}\text { Supply } \\
\text { KW/CFM }\end{array}$ & $\begin{array}{c}\text { Return } \\
\text { KW/CFM }\end{array}$ \\
\hline Suite A & 12930 & 13 & 11251 & 7.7 & 0.00071 & 0.00024 \\
Suite B & 14250 & 13 & 12400 & 7.7 & 0.00071 & 0.00024 \\
Suite D & 26924 & 13 & 23964 & 7.7 & 0.00071 & 0.00024 \\
Suite F & 25883 & 13 & 22211 & 7.7 & 0.00071 & 0.00024 \\
Suite H & 25498 & 13 & 21248 & 7.7 & 0.00071 & 0.00024 \\
Suite J & 38750 & 13 & 32291 & 7.7 & 0.00071 & 0.00024 \\
Suite K & 13335 & 13 & 11603 & 7.7 & 0.00071 & 0.00024 \\
\hline
\end{tabular}

Table 4. Proposed System Description

\begin{tabular}{|c|c|c|c|c|c|c|c|}
\hline \multirow[b]{2}{*}{ Zone } & \multicolumn{3}{|c|}{$\begin{array}{c}\text { Fans } \\
\text { Design Documents }\end{array}$} & \multicolumn{2}{|c|}{$\begin{array}{c}\text { Cooling } \\
\text { Design Documents }\end{array}$} & \multicolumn{2}{|c|}{$\begin{array}{c}\text { Heating } \\
\text { Design Documents }\end{array}$} \\
\hline & Supply CFM & OSA $^{9}$ & $\begin{array}{l}\mathrm{SP} \text { in } \\
\mathrm{WG}^{10}\end{array}$ & $\begin{array}{l}\text { Capacity } \\
\text { (Btu/h) }\end{array}$ & SEER & $\begin{array}{l}\text { Capacity } \\
\text { (Btu/h) }\end{array}$ & HSPF \\
\hline Suite A & 1200 & 150 & 0.5 & 35,200 & 15.2 & 32000 & 9 \\
\hline Suite B & 1200 & 150 & 0.5 & 35,200 & 15.2 & 32000 & 9 \\
\hline Suite D & 1600 & 150 & 0.5 & 35,200 & 15 & 45600 & 9.2 \\
\hline Suite F & 1400 & 150 & 0.5 & 35,200 & 15.2 & 42000 & 8.7 \\
\hline Suite H & 1600 & 150 & 0.5 & 35,200 & 15 & 46600 & 9.2 \\
\hline Suite J & 1600 & 150 & 0.5 & 35,200 & 15 & 45600 & 9.2 \\
\hline Suite K & 1200 & 150 & 0.5 & 35,200 & 15.2 & 32000 & 9 \\
\hline
\end{tabular}

${ }^{4}$ Autosized from simulation software.

${ }^{5} \mathrm{Btu} / \mathrm{h}$ is British thermal units per hour

${ }^{6}$ SEER is seasonal energy efficiency ratio

${ }^{7} \mathrm{HSPF}$ is heating seasonal performance factor

${ }^{8} \mathrm{KW} / \mathrm{CFM}$ is kilowatts per cubic feet per minute. This is calculated in accordance to ASHRAE 90.1 2007, Section G3.1.2.9

${ }^{9}$ OSA is Outside Air

${ }^{10} \mathrm{SP}$ in WG is Static Pressure in inches of Water Gauge 
The proposed system design has a higher efficiency rating and results in significant heating and cooling energy savings.

\subsection{Water Heating Systems}

The proposed building design uses a 100-gallon gas storage water heater with high thermal efficiency (95\%) and low stand-by losses. Several water efficiency measures reduced the water consumption by $54 \%$ for the proposed building design.

Table 5. Water Heater Calculations for Baseline and Proposed Design

\begin{tabular}{lccccccc}
\hline & \multicolumn{2}{c}{ Power } & Thermal Efficiency & \multicolumn{2}{c}{ Tank UA } \\
& $\begin{array}{l}\text { Volume } \\
\text { (gallons) }\end{array}$ & $\begin{array}{c}\text { Capacity } \\
\text { (Btu/hr) }\end{array}$ & $\begin{array}{c}\text { Capacity } \\
\text { (MBtu) }\end{array}$ & Efficiency & HIR & $\begin{array}{c}\text { Loss } \\
\text { (Btu/hr) }\end{array}$ & $\begin{array}{c}\text { Tank } \\
\text { UA }\end{array}$ \\
\hline $\begin{array}{l}\text { Proposed Model Description } \\
\text { AO Smith BTH-250 }\end{array}$ & 100 & 250,000 & 0.25 & $95 \%$ & 1.053 & 748 & 10.6857 \\
$\begin{array}{l}\text { Baseline Model Description } \\
\text { Gas Storage }>75,000 \text { Btu/hr }\end{array}$ & 100 & 250,000 & 0.25 & $80 \%$ & 1.25 & 1412.5 & 20.1786 \\
\hline
\end{tabular}

\subsection{Results}

The proposed design has design features that go above the ASHRAE 90.12007 requirements for building envelope, system efficiency as well as water heater efficiency, resulting in $27 \%$ energy savings over the ASHRAE 90.12007 baseline. Energy efficient lighting, high efficiency heat pumps as well as the high efficiency water heater results in most of the modeled savings. 



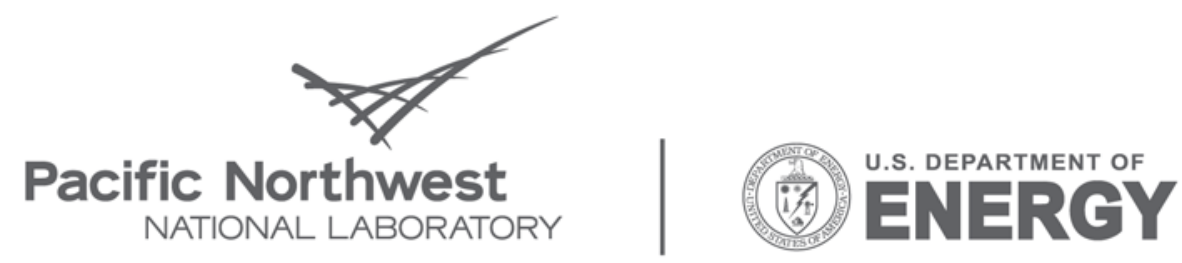

Proudly Operated by Battelle Since 1965

902 Battelle Boulevard

P.O. Box 999

Richland, WA 99352

1-888-375-PNNL (7665)

www.pnl.gov 